\title{
Water Activity Data Assessment to be used in Hanford Waste Solubility Calculations
}

\author{
R.S. Pistelliamp \\ Washington River Protection Sohtions LLC \\ Rkhland, WA 99352 \\ U.S. Department of Energy Contract DE-AC27-08RV14800 \\ EDTIECN: DRF UC: NA \\ Cost Center: 2GB00 Charge Code: \\ B\&R Code: N/A Total Pages: $25 \mathrm{Ft/6}$
}

Key Words: Water activity, molality, ionic strength, solubility, Hanford crystal phases, isopiestic, vapor pressure, osmotic coefficient

Abstract: The purpose of this report is to present and assess water sctivity versus ionic strength for six solutes:sodium nitratte, sodium nitrite, sodium chloride, sodium tarbonate, sodium sulfate, and potassium aitrate. Water activity is given versus molalíty (e.g. jonic strength) and temperature. Water activity is used to estimate Hanford crystal hydrate solubility present in the waste.

TRADEMARK DISCLAIMER. Reference herein to any specific commercial product proceso, ar onvico bry made name,

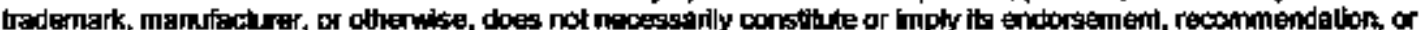
favoing by the United States Cowerninent or any agency thereof or lis contractors of eubeontracters.

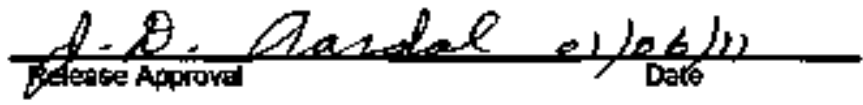

Approved For Public Release

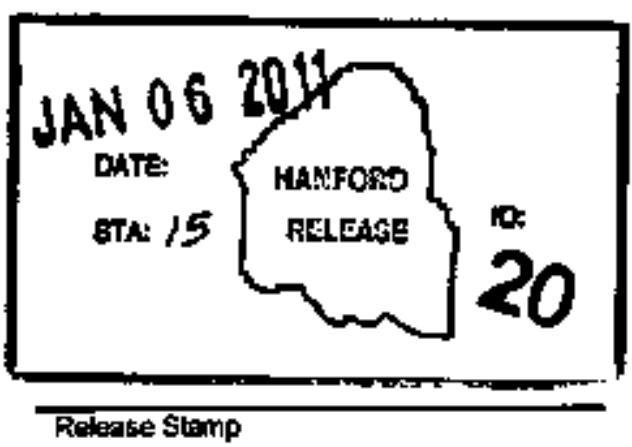




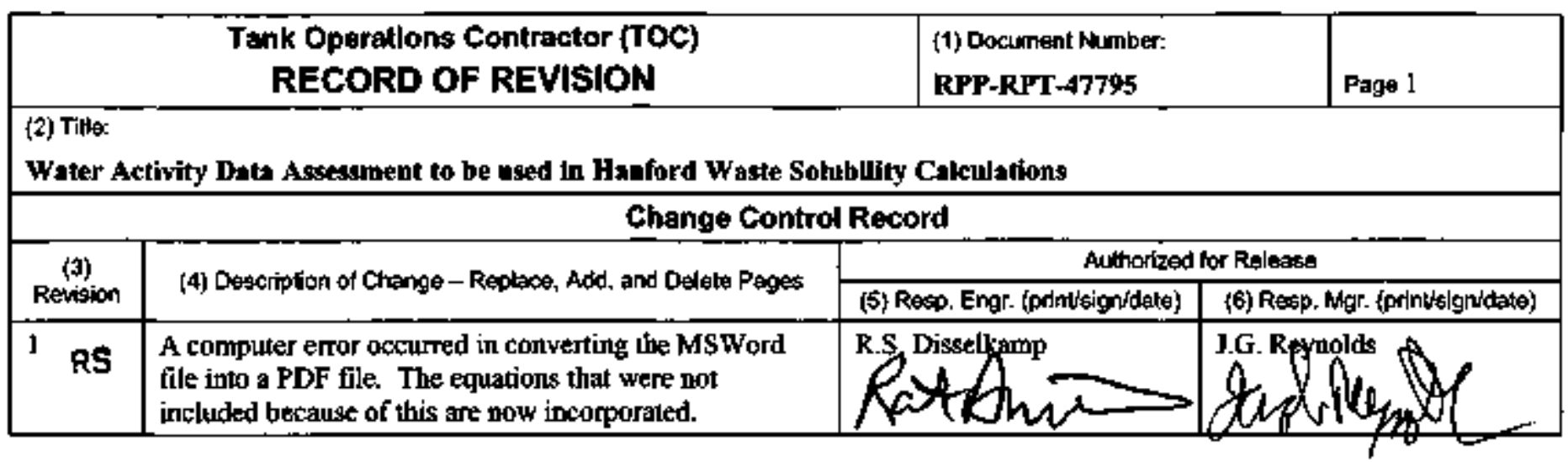

A-BO03-835 (REV 2) 


\title{
Water Activity Data Assessment to be used in Hanford Waste Solubility Calculations
}

\author{
R.S. Disselkamp \\ WTP Support - Washington River Protection Systems, LLC \\ Richland, WA 99352 \\ U.S. Department of Energy Contract DE-AC27-08RV14800
}

\section{EXTENDED ABSTRACT}

Complex equilibria exist between the aqueous phase and solid phases in Hanford waste. Because these solutions contain components at high concentration, it is necessary to accurately obtain parameterizations of water activity for retrieval, transfer, and for the vitrification plant at relevant temperatures and concentrations where storage, processing, and treatment are to be performed. This information can be used to accurately predict solid hydrates known to exist in Hanford waste. The solutes considered here, and those being some of the binary solute constituents in largest concentration, include $\mathrm{NaNO}_{3}, \mathrm{NaNO}_{2}, \mathrm{NaCl}, \mathrm{Na}_{2} \mathrm{CO}_{3}, \mathrm{Na}_{2} \mathrm{SO}_{4}$, and $\mathrm{KNO}_{3}$. Experimental data from the literature have been compiled and an assessment of the accuracy of this data, from which water activity data is to be extracted via unit conversions, is performed. Water activity is calculated from the experimental data, it is not directly reported in most cases. Attempts were made to use, as a first priority, experimental data that had not been smoothed, averaged, or calculated from a model of water activity. To accomplish this task, it was necessary to obtain original journal sources presenting multiple datasets of experimental data. In these cases of data assimilation, data from multiple sources under identical conditions was compared to assess their quality, when possible.

\section{KEY WORDS}

Water activity, molality, ionic strength, solubility, Hanford crystal phases, isopiestic, vapor pressure, osmotic coefficient. 


\section{TABLE OF CONTENTS}

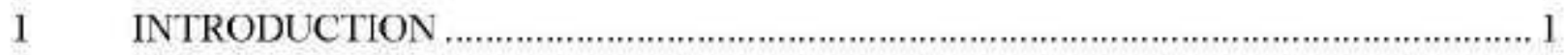

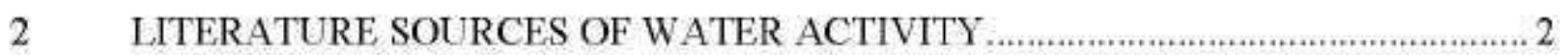

3 OBTAINING WATER ACTIVITY FROM DATA - DATA REDUCTION …............... 4

3.1 OSMOTIC COEFFICIENT DATA 4

3.2 WATER VAPOR PRESSURE MEASUREMENTS 4

3.3 ISOPIESTIC SOLUTE CONCENTRATIONS 5

3.4 ELECTROMOTIVE FORCE (EMF) MEASUREMENTS 5

4 ASSESSMENT OF FIDELITY OF WATER ACTIVITY DATA................................. 6

4.1 DISCUSSION OF DATASET AGREEMENT FOR EACH SOLUTE 6

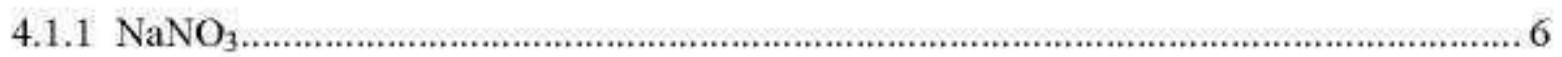

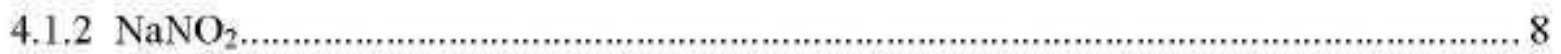

$4.1 .3 \mathrm{NaCl}$

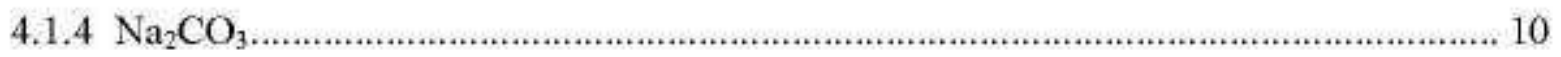

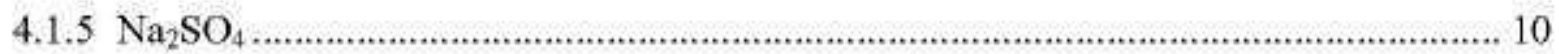

$4.1 .6 \mathrm{KNO}_{3} \ldots \ldots$

5 FUTURE WORK

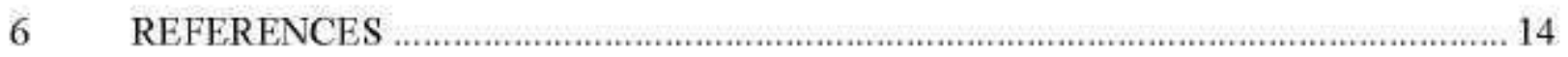

6.1 GENERAL REFERENCES 14

6.2 WATER ACTIVITY REFERENCES

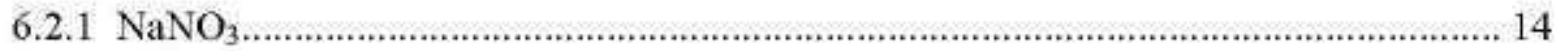

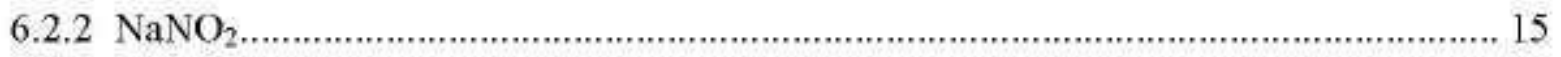

$6.2 .3 \mathrm{NaCl}$

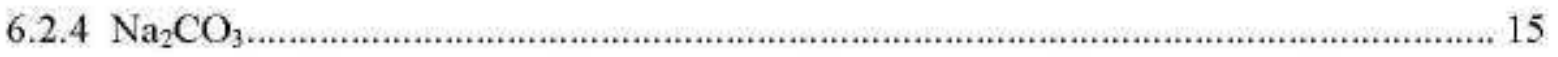

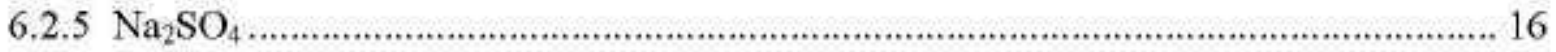

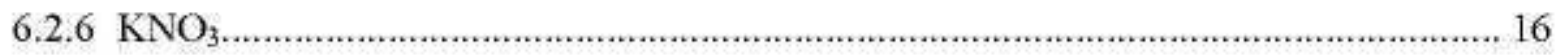




\section{TABLE OF FIGURES}

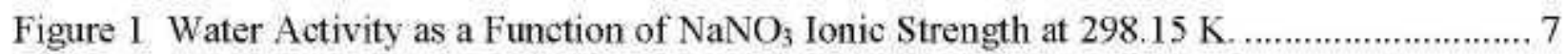

Figure 2. Water Activity as a Function of $\mathrm{NaNO}_{3}$ Ionic Strength at $323.15 \mathrm{~K}$........................ 8

Figure 3. Water Activity as a Function of $\mathrm{NaNO}_{2}$ Ionic Strength at $298.15 \mathrm{~K} \ldots \ldots \ldots \ldots \ldots \ldots \ldots . . . \ldots$

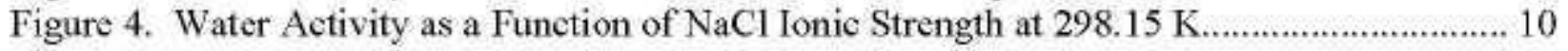

Figure 5. Water Activity as a Function of $\mathrm{Na}_{2} \mathrm{SO}_{4}$ Ionic Strength at $298.15 \mathrm{~K} \ldots \ldots \ldots \ldots \ldots \ldots \ldots \ldots . . . \ldots \ldots$

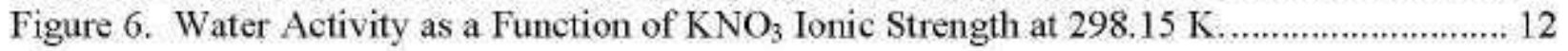

\section{TABLE OF TABLES}

Table 1. Single solute literature citations and concentration/temperature ranges of journal

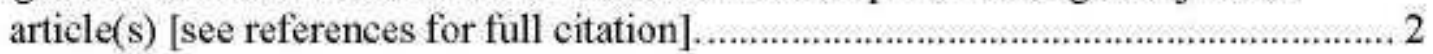


RPP-RPT-47795 Rev.1

\section{LIST OF TERMS}

$\begin{array}{ll}\begin{array}{l}\text { Abbreviations and Acronyms } \\ \text { BBI }\end{array} & \begin{array}{l}\text { Best-Basis Inventory } \\ \text { ECN }\end{array} \\ \text { TWINS } & \text { Tank Waste Inventory Network System } \\ & \\ \text { Units } & \\ \text { Celsius } & { }^{\circ} \mathrm{C} \\ \text { Kelvin } & \mathrm{K} \\ \text { kilopascals } & \mathrm{kPa} \\ \text { millibar } & \mathrm{mb} \\ \text { molal } & \mathrm{m}\end{array}$

Definitions

Osmotic coefficient $\emptyset$

Solution water vapor pressure $\quad P$

Pure water vapor pressure $\quad P_{0}$

Water activity $\quad a_{w}$ 


\section{INTRODUCTION}

In this report, an assessment of single solute experimental water activity data is presented for a limited number of compounds. The components considered here are sodium and potassium salts that represent the components present in significant concentration in Hanford waste. Accurate parameterizations of water activity are needed to estimate many solid hydrate phases present, under equilibrium, in Hanford waste storage, processing, and treatment conditions. The fitting of functions of water activity data are not performed here, but will be the focus of a future report.

The thermodynamic property of water activity can be obtained from a variety of sources. In essence, unit conversions are required to express/convert equivalent data types into water activity. Data types include osmotic coefficients, water vapor pressure measurements, isopiestic salt concentrations using unknown and reference solutions, and electrochemical cell potential measurements. For water vapor measurements above salt solutions, the pure water vapor pressure at the same solution temperature must be known. In all but osmotic coefficient measurements, temperature must be known to compute water activity. The investigation of water activity for single solutes as a function of concentration and temperature (preferred range of $25-100^{\circ} \mathrm{C}$ ) was implemented using a three step procedure as given below.

1. Obtain literature sources [joumal articles or textbooks] listing experimental data from which water activity can be derived.

2. Perform unit conversions from raw data to obtain water activity versus molal, and consequently ionic strength, for each solute.

3. Perform assessment of water activity data. In particular, the distribution of error (i.e., random and or systematic errors) for each solute was examined. Our discussion here will focus primarily on the origin of systematic, and to a lesser extent random, errors associated with experimental measurements.

The water activity data obtained here will be fit to a model in a future report and used to estimate compound solubility for solutes whose solubility is intermediate between nearly freely soluble (e.g., large solubility) and insoluble under waste storage and processing conditions [RPP-PLAN-46002, Wash and Leach Factor Work Plan report]. Solubility modeling of components in Hanford waste is important because mixing waste types, caustic additions, evaporator campaigns, tank transfers and retrievals, and staging of waste to be sent to the waste treatment complex all rely upon knowing the partitioning of waste among solid and aqueous (e.g., dissolved) forms. 


\section{LITERATURE SOURCES OF WATER ACTIVITY}

An extensive literature review identified experimental literature data, from which water activity can be computed, for single solutes applicable to tank waste storage and treatment conditions of high concentration and $25^{\circ} \mathrm{C}$ to elevated temperature. For example, concentrations of anions up to 8 molal and sodium to 14 molal are preferred (RPP-PLAN-46002), within the temperature range of $25-100^{\circ} \mathrm{C}$. In addition, we restricted efforts here to examine components known to be in large concentration from the Best Basis Inventory (BBI) (TWINS; 2010). Table 1 presents the literature data sources (see reference section for full citations) of the 6 binary components we examine here. The abbreviated literature citations presented in Table 1 correspond to their full citations, given according to solute type, in the Reference section. In a latter revision of this report data for additional electrolytes (e.g., solutes) will be presented.

Table 1. Single solute literature citations and concentration/temperature ranges of journal article(s) [see references for full citation].

\begin{tabular}{|c|c|c|c|c|c|}
\hline Solute & Literature Citation & $\begin{array}{c}\text { Dataset } \\
\text { Designation }\end{array}$ & $\begin{array}{c}\text { Data Type } \\
\text { [see footnote } \\
\text { for } \\
\text { explanation] }\end{array}$ & $\begin{array}{l}\text { Concentration } \\
\text { Range (molal) }\end{array}$ & $\begin{array}{c}\text { Temperature } \\
\text { Range } \\
\text { (K) }\end{array}$ \\
\hline $\mathrm{NaNO}_{3}$ & $\begin{array}{c}\text { Galleguillos, Salavera, } \\
\text { Vargas, Coronas, } 2010 \\
\text { Apelblat, Korin, } 1998 \\
\text { Voight, } 1990 \\
\text { Bossman, } 1993 \\
\text { Pearce, } 1937 \\
\text { Kangro, Groeneveld, } \\
1962\end{array}$ & $\begin{array}{l}\mathrm{NaNO}_{3}-\mathrm{B} \\
\mathrm{NaNO}_{3}-\mathrm{E} \\
\mathrm{NaNO}_{3}-\mathrm{H} \\
\mathrm{NaNO}_{3}-\mathrm{K} \\
\mathrm{NaNO}_{3}-\mathrm{I} \\
\mathrm{NaNO}_{3}-\mathrm{G}\end{array}$ & $\begin{array}{l}E(O) \\
E(V P) \\
E(V P) \\
E(V P) \\
E(V P) \\
E(V P)\end{array}$ & $0.001-52$ & $273-492$ \\
\hline $\mathrm{NaNO}_{2}$ & $\begin{array}{c}\text { Galleguillos, Salavera, } \\
\text { Vargas, Coronas, } 2010 \\
\text { Ray, Ogg, } 1956 \\
\text { Chekhouva, Protsenko, } \\
1967\end{array}$ & $\begin{array}{l}\mathrm{NaNO}_{2}-\mathrm{A} \\
\mathrm{NaNO}_{2}-\mathrm{D} \\
\mathrm{NaNO}_{2}-\mathrm{B}\end{array}$ & $\begin{array}{l}E(V P) \\
E(O) \\
E(V P)\end{array}$ & $0.1-12.3$ & $298-353$ \\
\hline $\mathrm{NaCl}$ & $\begin{array}{c}\text { Apelblat, Korin, } 1998 \\
\text { Gibbard Jr,Scatchard, } \\
\text { Rousseau, Creek, } 1974 \\
\text { Hubert, Gabes, Bourdet, } \\
\text { Schuffenecker, } 1995 \\
\text { Olynyk, Gordon, } 1943\end{array}$ & $\begin{array}{l}\mathrm{NaCl}-\mathrm{A} \\
\mathrm{NaCl}-\mathrm{D} \\
\mathrm{NaCl}-\mathrm{C} \\
\mathrm{NaCl}-\mathrm{E}\end{array}$ & $\begin{array}{l}E(V P) \\
E(O) \\
E(V P) \\
E(V P)\end{array}$ & $1.0-6.2$ & $278 \cdot 373$ \\
\hline $\mathrm{Na}_{2} \mathrm{CO}_{3}$ & $\begin{array}{c}\text { Vanderzee, } 1982 \\
\text { Appleblat, Manzurola, } \\
2003 \\
\text { Robinson, Macaskill, } \\
1979 \\
\text { Taylor, } 1955\end{array}$ & $\begin{array}{c}\mathrm{Na}_{2} \mathrm{CO}_{3}-\mathrm{A}, \mathrm{B} \\
\mathrm{Na}_{2} \mathrm{CO}_{3}-\mathrm{C} \\
\\
\mathrm{Na}_{2} \mathrm{CO}_{3}-\mathrm{D}, \mathrm{F} \\
\mathrm{Na}_{2} \mathrm{CO}_{3}-\mathrm{G}\end{array}$ & $\begin{array}{l}\mathrm{E}(\mathrm{FP}) \\
\mathrm{E}(\mathrm{O}) \\
\mathrm{E}(\mathrm{O}) \\
\mathrm{E}(\mathrm{VP})\end{array}$ & $0.0001-4.56$ & $273-368$ \\
\hline
\end{tabular}


Table 1. Single solute literature citations and concentration/temperature ranges of journal article(s) [see references for full citation].

\begin{tabular}{|c|c|c|c|c|c|}
\hline Solute & Literature Citation & $\begin{array}{c}\text { Dataset } \\
\text { Designation }\end{array}$ & $\begin{array}{l}\text { Data Type } \\
\text { [see footnote } \\
\text { for } \\
\text { explanation] }\end{array}$ & $\begin{array}{l}\text { Concentration } \\
\text { Range (molal) }\end{array}$ & $\begin{array}{c}\text { Temperature } \\
\text { Range } \\
\text { (K) }\end{array}$ \\
\hline $\mathrm{Na}_{2} \mathrm{SO}_{4}$ & $\begin{array}{l}\text { Rard, Clegg, Palmer, } \\
\text { 2000 } \\
\text { Rard, Miller, } 1981 \\
\text { Robinson, Wilson, } \\
\text { Stokes, } 1941 \\
\text { Leopold, Johnston, } 1927 \\
\text { Guendouzi, Mounir, } \\
\text { Dinane, } 2003 \\
\text { Gibson, Adams, } 1933 \\
\text { Humphries, Kohrt, } \\
\text { Patterson, } 1968 \\
\text { Moore, Humphries, } \\
\text { Patterson, } 1972 \\
\text { Hellams, Patterson, } \\
\text { Prentice, Taylor, } 1965 \\
\text { Patterson, Gilpatrick, } \\
\text { Soldano, } 1960 \\
\text { Soldano, Patterson, } 1962\end{array}$ & $\begin{array}{l}\mathrm{Na}_{2} \mathrm{SO}_{4}-\mathrm{I} \\
\mathrm{Na}_{2} \mathrm{SO}_{4}-\mathrm{H} \\
\mathrm{Na}_{2} \mathrm{SO}_{4}-\mathrm{C} \\
\mathrm{Na}_{2} \mathrm{SO}_{4}-\mathrm{D} \\
\mathrm{Na}_{2} \mathrm{SO}_{4}-\mathrm{A} \\
\mathrm{Na}_{2} \mathrm{SO}_{4}-\mathrm{B} \\
\mathrm{Na}_{2} \mathrm{SO}_{4}-\mathrm{M} \\
\mathrm{Na}_{2} \mathrm{SO}_{4}-\mathrm{N} \\
\mathrm{Na}_{2} \mathrm{SO}_{4}-\mathrm{L} \\
\mathrm{Na}_{2} \mathrm{SO}_{4}-\mathrm{G} \\
\mathrm{Na}_{2} \mathrm{SO}_{4}-\mathrm{J}\end{array}$ & $\begin{array}{l}E(I) \\
E(I) \\
E(V P) \\
E(V P) \\
E(O) \\
E(V P) \\
E(O) \\
E(T) \\
E(O) \\
E(O) \\
E(O)\end{array}$ & $0.05-40$ & $273-398$ \\
\hline $\mathrm{KNO}_{3}$ & $\begin{array}{c}\text { Guendouzi, Mounir, } \\
\text { Dinane, } 2003 \\
\text { Shpigol, Mishchenko, } \\
1967 \\
\text { Robinson, } 1935 \\
\text { Kangro, Groeneveld, } \\
1962\end{array}$ & $\begin{array}{l}\mathrm{KNO}_{3}-\mathrm{B} \\
\mathrm{KNO}_{3}-\mathrm{C} \\
\mathrm{KNO}_{3}-\mathrm{D} \\
\mathrm{KNO}_{3}-\mathrm{E}\end{array}$ & $\begin{array}{l}E(V P) \\
E(V P) \\
E(V P) \\
E(V P)\end{array}$ & $0.115-5.68$ & $270-393$ \\
\hline
\end{tabular}

In the cited literature, water activity as a function of concentration and temperature is either given directly as water activity, as osmotic coefficient, or as water vapor pressure above the salt solution. All three of these data types are alternative, and equivalent, ways of expressing water activity. Many measurements are required, preferably from multiple data sources to ensure independent determinations free from systematic errors, for each solute in order to fit a model of the water activity datasets. The latter will be performed in a separate follow-on report. 


\section{OBT AINING WATER ACTIVITY FROM DATA - DATA REDUCTION}

As mentioned in the introduction, numerous methods exist to obtain water activity. These include osmotic coefficients, water vapor pressure measurements, isopiestic salt concentrations using unknown and reference solutions, and electrochemical cell potential measurements. The transformation of each of these quantities into water activity data was performed as described below.

\subsection{OSMOTIC COEFFICIENT DATA}

One of the more common ways of expressing water activity is via osmotic coefficient. The relationship between osmotic coefficient, $\emptyset$, and water activity, $a_{w}$, is given in Eqn.(1) below (Zemaitis et al., 1986).

$$
a_{w}=\exp \left[-\emptyset v m\left(\frac{18.0153}{1000}\right)\right]
$$

In Eqn.(1) $v$ is the number of dissociated solute anionic or cationic moles per 1 mole of complete solute formula unit (e.g., for $\mathrm{Na}_{2} \mathrm{CO}_{3} v=3$ ), and $\mathrm{m}$ is the molality of the solute species (e.g., for $\mathrm{Na}_{2} \mathrm{CO}_{3}$ ). It is preferred to have data of osmotic coefficient versus a range of temperature and concentration in order to extract water activities over Hanford-relevant conditions.

\subsection{WATER VAPOR PRESSURE MEASUREMENTS}

It is a straightforward process to convert measured water vapor pressures above salt solutions, at known temperature, into water activities. The pertinent equation used is (Zemaitis et al., 1986):

$$
a_{w}=\frac{p}{p_{o}}
$$

Where $\mathrm{P}$ is the water yapor pressure for the salt solution $(\mathrm{mb})$ and $\mathrm{P}_{\mathrm{o}}$ is the pure water vapor pressure (at the same temperature) in $\mathrm{mb}$. The Murray equation has been employed to compute the pure water vapor pressure as a function of temperature. The functional form of this equation was originally proposed by Goff and Gratch (1946). The Murray equation computes water vapor pressure in equilibrium with pure water and is given in the equation below (Murray, 1967):

$$
\begin{array}{r}
\log \left(e_{S W}\right)=-7.90298 \times\left(\frac{\mathrm{T}_{5}}{\mathrm{~T}}-1\right)+5.02808 \times \log \left(\frac{\mathrm{T}_{\mathrm{S}}}{\mathrm{T}}\right)-1.3816 \times 10^{-7} \times \\
{\left[10^{11.344 \times\left(1-\frac{\mathrm{T}}{\mathrm{T}_{s}}\right)}-1\right]+8.1328 \times 10^{-3} \times\left[10^{3.49149 \times\left(\frac{\mathrm{T}_{s}}{\mathrm{~T}}-1\right)}-1\right]+\log \left(e_{w S}\right)}
\end{array}
$$

Where $T$ is temperature $(\mathrm{K}), T_{s}=373.16 \mathrm{~K}$, and $e_{w s}=1013.246$ for water vapor pressure in mbar. [Note that the subscripts on the "e" terms are different.]

The pressure (mbar) for pure water is then given by Eqn.(4) below.

$$
P_{o}=10^{\log \left(e_{s w}\right)}
$$

The units of Eqn(4) are mbar pressure units for correct inclusion into Eqn(2). 


\subsection{ISOPIESTIC SOLUTE CONCENTRATIONS}

A third type of method for water activity measurement can be made is from isopiestic solutions. In these measurements, a semi-permeable membrane is used to enable water transport separates two salt compartments and a common water vapor pressure measurement is made simultaneously for both compartments. Our approach is to compute water activity using the Aseyev equation for the known (i.e. reference) salt solution concentration and by equivalence set this equal to the identical water activity of the different salt concentration for the species of interest. Thus isopiestic measurements are datasets containing two salt concentrations at a given temperature, at equilibrium with the same water vapor pressure.

Water activities were computed for reference isopiestic solutions using the Aseyev equation (Aseyev, 1999). The pertinent equations are as follows:

$$
a_{W}=\sum_{i=1}^{k} m_{i} P_{i}^{*}
$$

Where

$$
P_{i}^{i}=W_{0 i}+W_{1 i} t_{i}+W_{2 i} m_{i}+W_{3 i} t_{i}^{2}+W_{4 i} t_{i} m_{i}+W_{5 i} t_{i}^{2} m_{i}
$$

And

$\mathrm{t}_{\mathrm{i}}$ is temperature in Celsius

$\mathrm{m}_{\mathrm{i}}$ is concentration in molality

$\mathrm{W}_{\mathrm{i}}$ values are known solute-specific parameters (Aseyev, 1999).

The $\mathrm{W}$ parameters in Eqn(6) are known for typical reference solutes such as $\mathrm{NaCl}$ and $\mathrm{KCl}$, among others (Aseyev, 1999).

\subsection{ELECTROMOTIVE FORCE (EMF) MEASUREMENTS}

Electromotive Force measurements used the Nemst equation relating cell potential to solute activity. The general form of the equation, which varies somewhat according to standard state of each unique system, can be written as:

where

$$
\Delta E=\frac{k T}{n F} \ln (K)
$$

$$
K=\frac{a}{a_{\text {reference }}}
$$

Here $\Delta E$ is the measured cell potential (V), T is temperature (K), R and $\mathrm{F}$ are the ideal gas law and Faraday constants, respectively, and $\mathrm{n}$ is the number of electrons involved in the reductionoxidation reaction. In addition, the "a" parameter is the activity constant term of the solution (that contains $\mathrm{a}_{\mathrm{w}}$ ), and " $\mathrm{a}_{\text {reference" }}$ are related to the standard, or known, reference cell concentrations. Typically $a_{\text {seference }}$ is known and $a_{w}$ is computed from given solutions concentrations and Eqns(7) and (8). Although none of the data presented here involved EMF measurements, future use may be made of this data type. 


\section{ASSESSMENT OF FIDELITY OF WATER ACTIVITY DATA}

In this section an assessment of water activity either derived or directly measured using literature data for each solute is performed. This is accomplished through a discussion of water activity plotted against solution ionic strength. It is not necessary that any specific functional form describe such plots, however agreement of all separate datasets is necessary. The dataset outliers are discussed and identified. Another type of "suspect" data that could be encountered was that which exhibited an unusually large random error deviation about the trend-curve average of the datasets.

\subsection{DISCUSSION OF DATASET AGREEMENT FOR EACH SOLUTE}

The purpose of this section of the report is to evaluate the self-consistency of the water activity data. There is, in this section, data from more than one study for each electrolyte. In those cases, it is desirable to see how the two or more datasets compare to determine if the data is selfconsistent. When the datasets are not self-eonsistent, particularly if one is an outlier compared to many datasets, it is an indication that there might be a problem with the data. It may or may not be possible to identify the cause, but it is desirable to know if there is problematic data within a set. Hence, when there are several datasets that agree with each other and one dataset that does not agree we have chosen to exclude the inconsistent dataset from future modeling work.

Experimental measurements of water activity are less common at temperatures above $298 \mathrm{~K}$, so an inter-comparison between datasets is not always possible. We have opted to cite all studies for these elevated temperatures [see Table 1] and include them in our reference list. Therefore, this section only discusses data inter-comparison where more than one dataset exists at a given temperature. This often restricts our discussion here to $298 \mathrm{~K}$ where more datasets exist. In a future report, discussing the modeling of water activity, further evaluation of the suitability of these datasets will be made.

\subsection{1 $\mathrm{NaNO}_{3}$}

For $\mathrm{NaNO}_{3}$, there are five datasets that have two or more data points at $298.15 \mathrm{~K}$. The water activity in these datasets is plotted as a function of ionic strength in Figure 1. As can be seen from this plot, the overwhelming majority of the data are reasonably self-consistent with each other. The exception is the data by Galleguillos et al. (2010), which does not appear to be consistent with the other data. 
Figure 1 Water Activity as a Function of $\mathrm{NaNO}_{3}$ Ionic Strength at $298.15 \mathrm{~K}$.

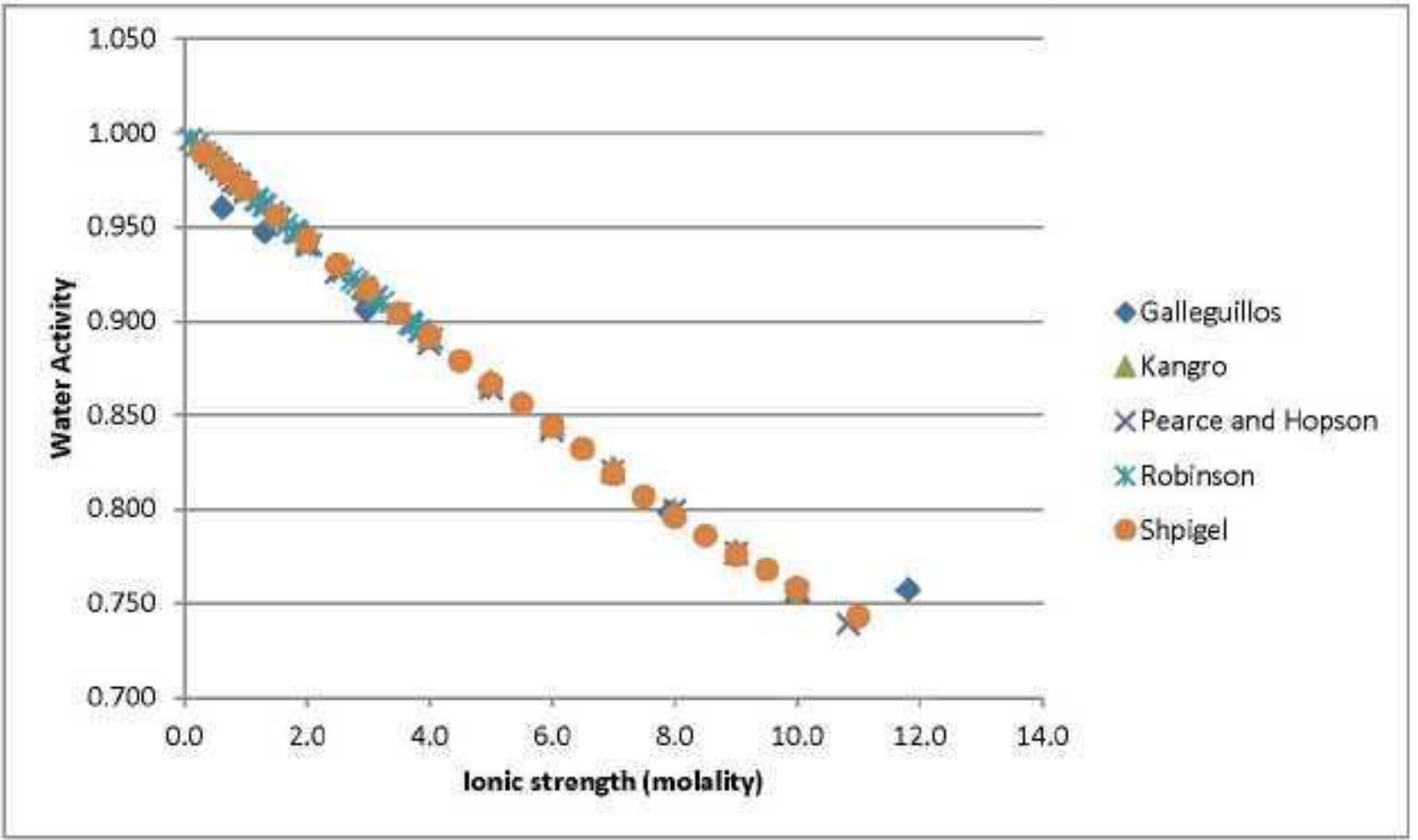

Figure 2 compares the data at $323.15 \mathrm{~K}$ reported by Shpigel et al. (1967) and Galleguillos et al. (2010). As can be seen from this figure, there is good agreement between these two studies, but there is more scatter in the Galleguillos dataset. There were also inconsistencies (though not large) between the Galleguillos data and all other datasets at $298.15 \mathrm{~K}$. However, the Galleguillos dataset was included because the inconsistencies were not too large and because this dataset covers a large temperature and concentration range that is not covered by most other datasets. The Shpigel dataset, because it resulted from smoothing, will not be considered further for use, but serves as a good comparison tool to the other datasets because of its completeness. 
Figure 2. Water Activity as a Function of $\mathrm{NaNO}_{3}$ Ionic Strength at $323.15 \mathrm{~K}$.

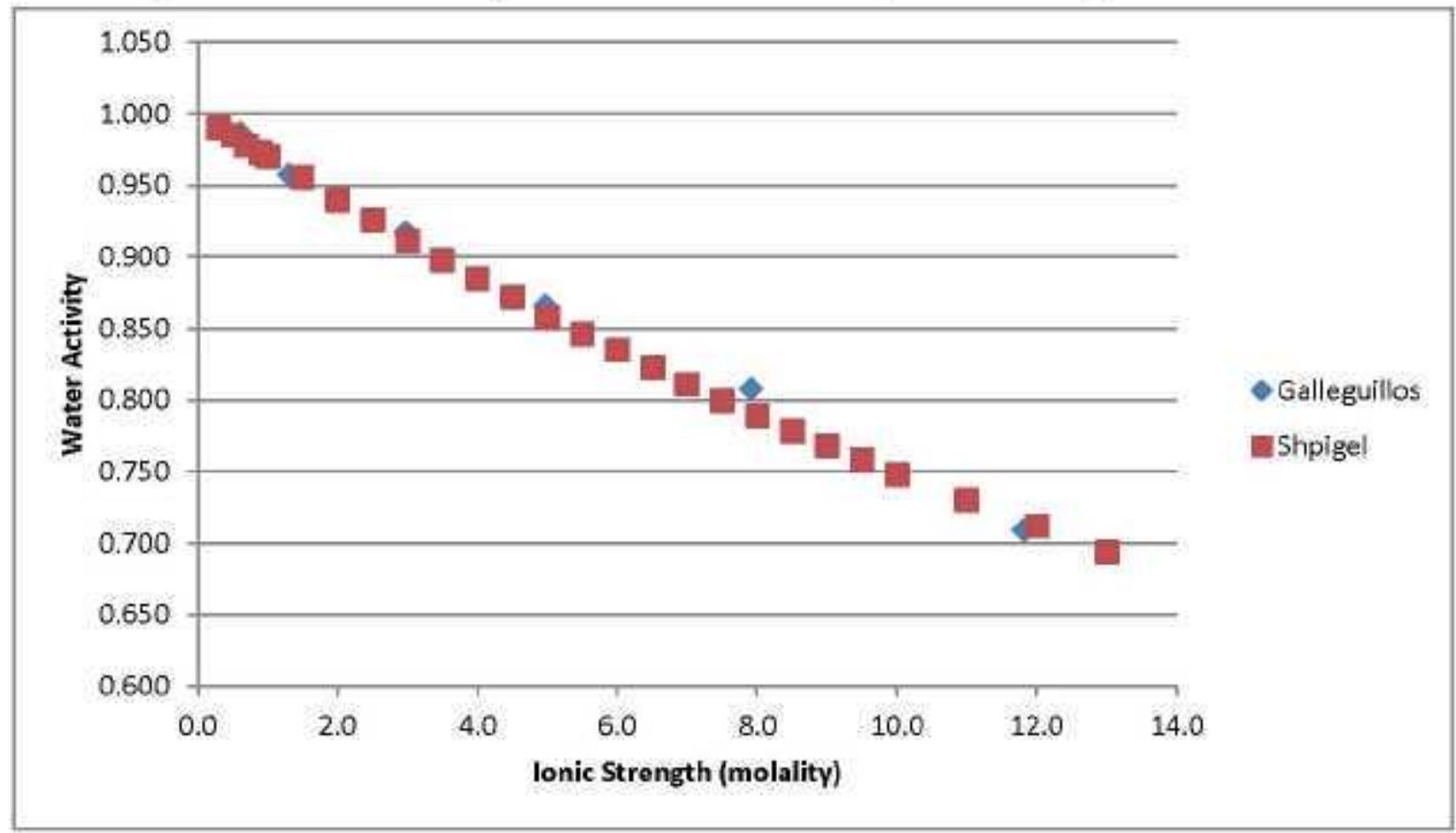

Most datasets held temperature constant and varied the ionic strength. Apelblat and Korin (1998) changed both temperature and concentration in their study, which could explain the inconsistencies between their $298 \mathrm{~K}$ data and other datasets [data not shown]. In addition, their single $323 \mathrm{~K}$ data point does not agree with other data at that temperature. Their dataset was collected at saturation with respect to $\mathrm{NaNO}_{3}$, so there might have been an error in either the water activity measurement or measurement of the saturated solution concentration. The Apelblat and Korin (1998) data was not used in the present study, despite the inconsistencies being small.

The dataset of Voight et al. (1990) only has data at $373.45 \mathrm{~K}$ and it is the only dataset at this temperature. Thus, this data set was assumed to be aceeptable in the absence of any contrary data.

\subsection{2 $\mathrm{NaNO}_{2}$}

There are three datasets available at $298.15 \mathrm{~K}$ for the $\mathrm{NaNO}_{2}$ system. Of the three, only the dataset of Galleguillos (Galleguillos et al. 2010) has data at temperatures other than $298.15 \mathrm{~K}$. The data collected at $298.15 \mathrm{~K}$ is plotted in Figure 3. As can be seen in Figure 3, the Galleguillos data is slightly inconsistent with the other two datasets at $298.15 \mathrm{~K}$. Nonetheless, the Galleguillos dataset will be used in modeling because it is the only dataset available at any temperature other than $298.15 \mathrm{~K}$, and because the discrepancy at $298.15 \mathrm{~K}$ was not large (Figure 3). Given the uncertainty in the quality of the Galleguillos $\mathrm{NaNO}_{2}$ dataset, additional data for the $\mathrm{NaNO}_{2}$ system at temperatures other than $298.15 \mathrm{~K}$ would greatly improve the confidence of our model to predict the water activity of waste with large concentrations of $\mathrm{NaNO}_{2}$, particularly at elevated temperature. 
Figure 3. Water Activity as a Function of $\mathrm{NaNO}_{2}$ Ionic Strength at $298.15 \mathrm{~K}$.

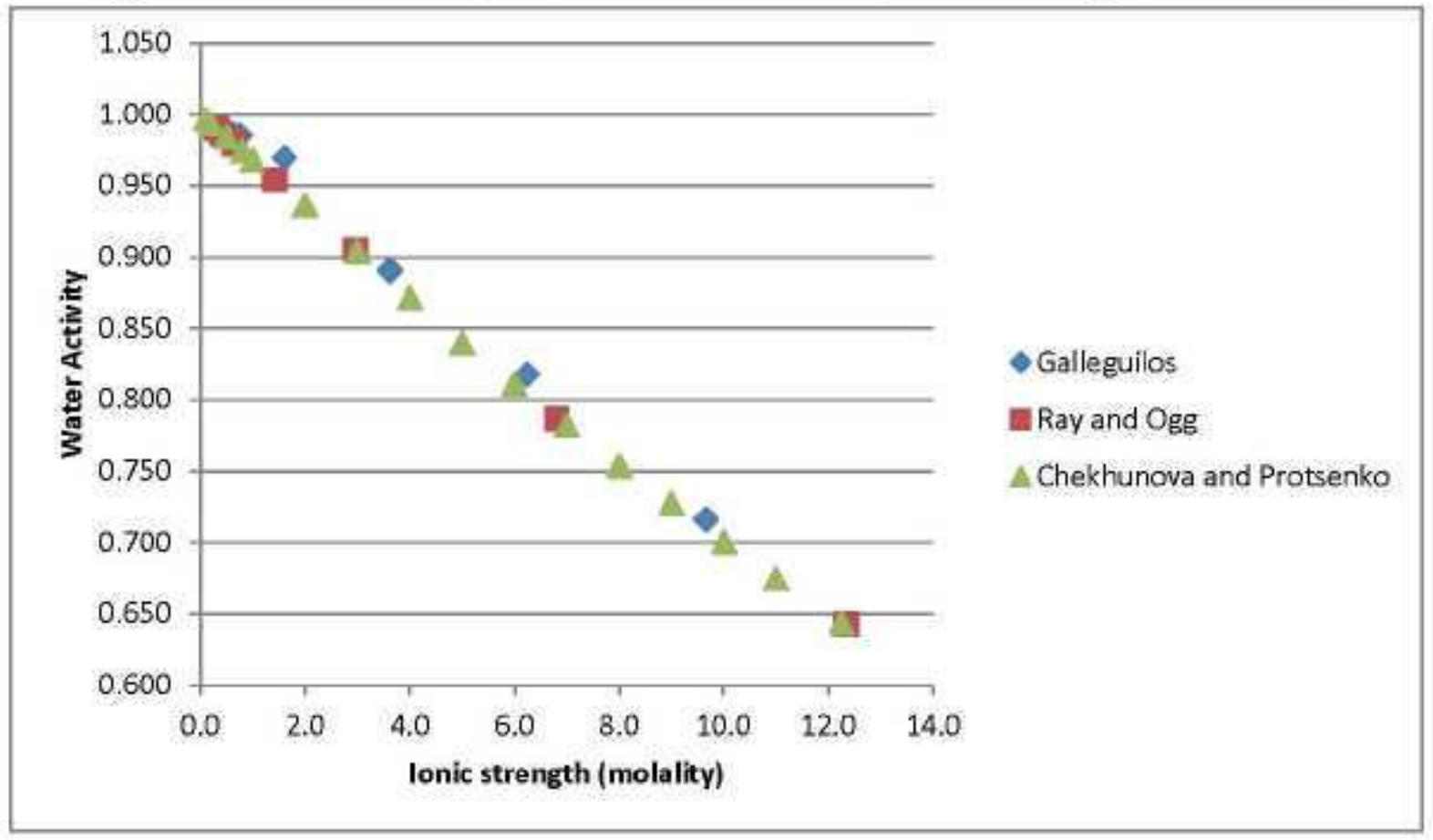

\subsubsection{NaCl}

There are two $\mathrm{NaCl}$ datasets available (Gibbard et al., 1974, Olynyk and Gordon, 1943) with data points at $298.15 \mathrm{~K}$, plotted in Figure 4. As can be seen in Figure 4, there is good agreement between these two datasets at 298.15. Therefore, it is assumed that these are both good datasets at other temperatures as well. A third dataset (Hubert et al., 1995) has data points that range from $294 \mathrm{~K}$ to $368 \mathrm{~K}$. Their data points at $299 \mathrm{~K}$ are very close to the data at $298.15 \mathrm{~K}$ of the other two datasets. Thus, the Hubert et al. (1995) dataset is also used in this study.

Appelblat and Korin (1998) report one data point at $298.15 \mathrm{~K}$, and this data point is also consistent with the other data at $298.15 \mathrm{~K}$. At an ionic strength of 6.15 molal, Appelblat and Korin (1998) report a water activity of 0.751 , where as the other datasets have a water activity near 0.755 . Thus, the Appelblat and Korin data is also assumed to be acceptable data and is used in this study. The rest of the data reported by Appelblat and Korin (1998) is at temperatures or composition regions that are not comparable to other datasets so cannot be cross checked. 
Figure 4. Water Activity as a Function of NaCl Ionic Strength at $298.15 \mathrm{~K}$.

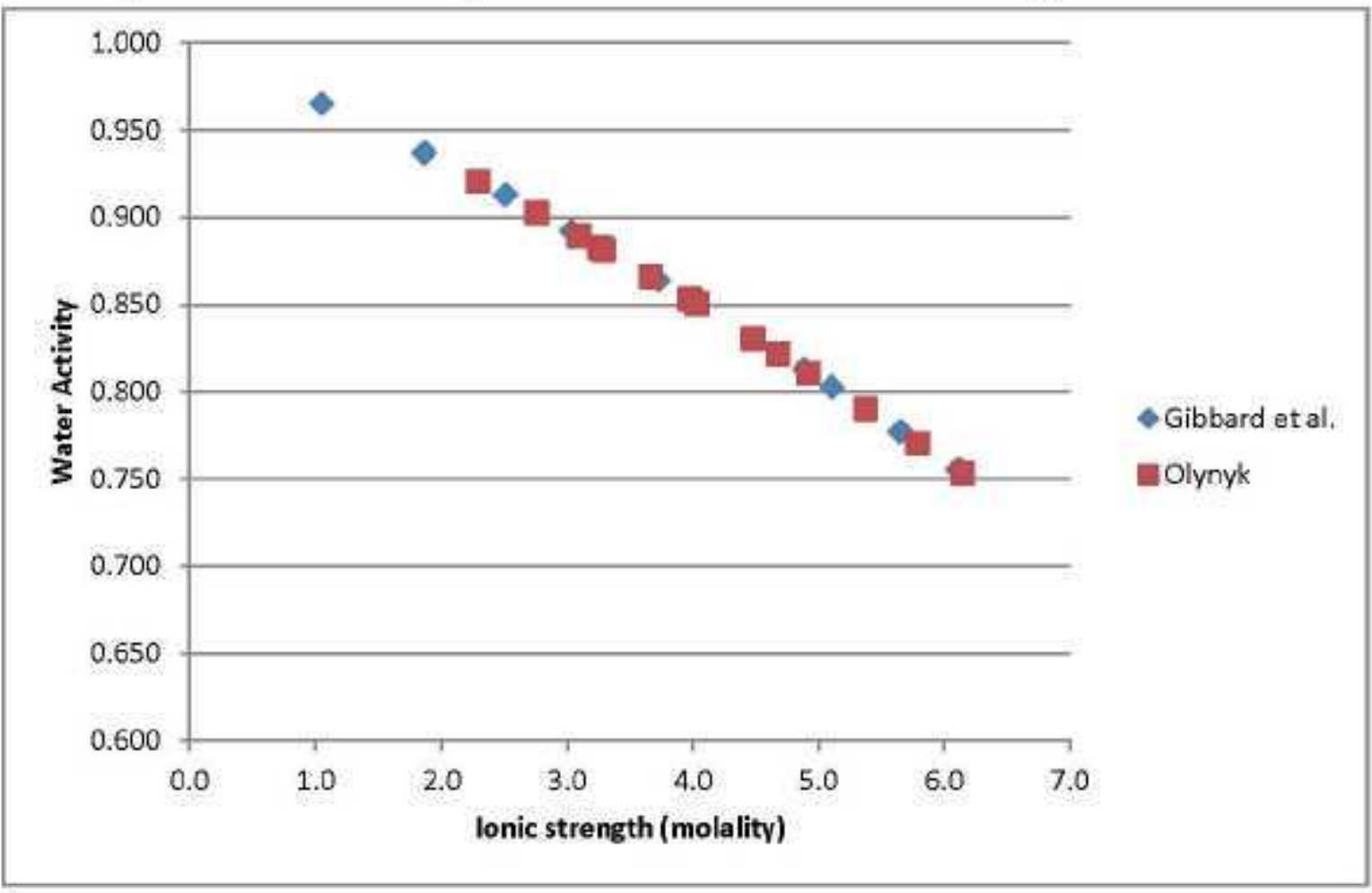

\subsection{4 $\mathrm{Na}_{2} \mathrm{CO}_{3}$}

There are only two datasets available for $\mathrm{Na}_{2} \mathrm{CO}_{3}$ (Robinson and Macaskill, 1979; Taylor, 1955). Neither of these datasets covered the same temperature range. Thus, these datasets were assumed to be acceptable, based on the lack of conflicting evidence. There are other datasets in the literature for the $\mathrm{Na}_{2} \mathrm{CO}_{3}$ system, but we have not been able to gain access to them in time for the present revision of this report. This report will be updated with the new datasets when the authors have obtained copies of those studies.

\subsection{5 $\mathrm{Na}_{2} \mathrm{SO}_{4}$}

There are four datasets (Guendouzi et al., 2003; Rard and Miller, 1981; Rard et al., 2000; Robinson et al., 1941) available in the $\mathrm{Na}_{2} \mathrm{SO}_{4}$ system with data at $298.15 \mathrm{~K}$. Figure 5 plots these data and shows that all four are consistent with each other. There is additional data, reported by Gibson et al (1933), with data at $300 \mathrm{~K}$. These data at $300 \mathrm{~K}$ are not appreciably different than the data at $298.15 \mathrm{~K}$ shown in Figure 3, as expected for such a small temperature change. Thus, all five of these datasets are considered self consistent and will be used in this study. 
Figure 5. Water Activity as a Function of $\mathrm{Na}_{2} \mathrm{SO}_{4}$ Ionic Strength at $298.15 \mathrm{~K}$.

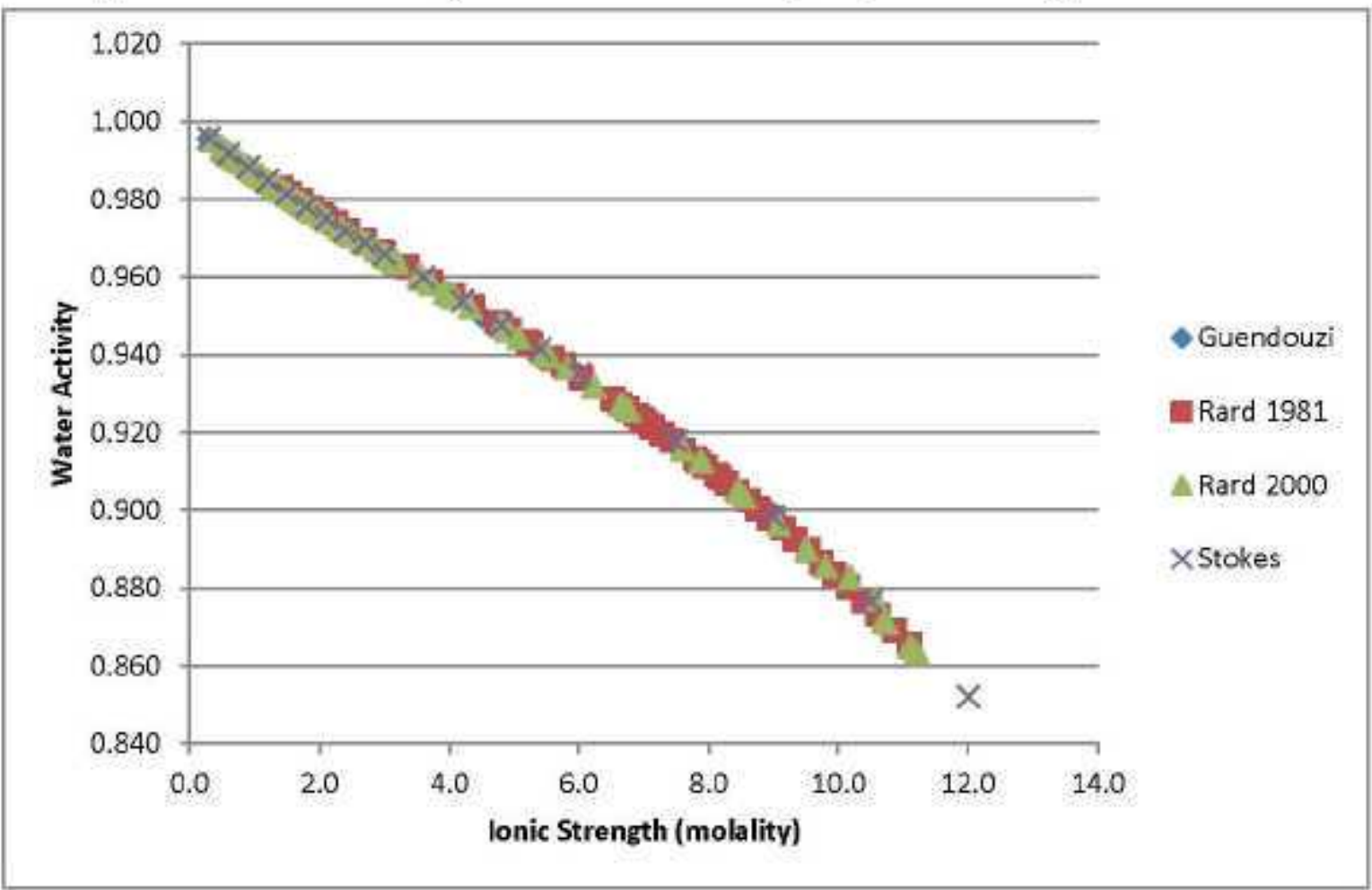

The data in Leopold et al. (1927) does not appear to be consistent with other datasets. The Leopold et al. (1927) data changes both ionic strength and temperature because they measured the water activity in solutions that are at saturation with respect to sodium sulfate. At $298.15 \mathrm{~K}$, Leopold et al. (1927) predicts a saturation vapor pressure of 0.860 , which is very close to the 0.866 reported by Rard (1981) and the value of 0.865 reported by Rard et al. (2000). However, the ionic strengths at saturation are very different between the Rard et al. $(1981 ; 2000)$ and the Leopold et al. (1927) data (9.5 molal versus 11.1 molal in Rard, 1981). Thus, there appears to be an error in the concentration at saturation reported by Leopold et al. (1927) and, therefore, these data were excluded from the study.

\subsection{6 $\mathrm{KNO}_{3}$}

There are three datasets (Guendouzi et al., 2003; Shpigel et al., 1967; Robinson, 1935) for the $\mathrm{KNO}_{3}$ system that has data at $298.15 \mathrm{~K}$. Because the Shpigel dataset was smoothed, it is used for comparison only. These four datasets are plotted in Figure 6, below. As can be seen in this figure, all four datasets are self-consistent. Thus, the data from all four datasets will be used for model development. A fourth dataset also has three data points at $298.15 \mathrm{~K}$ (Kangro et al., 1962), which were too few to plot in Figure 6, but also were consistent with the other datasets. Kangro et al. (1962) also reported three data points at $293.15 \mathrm{~K}$, which were assumed to be consistent with the other data because this same study had consistent data at $298.15 \mathrm{~K}$. 
RPP-RPT-47795 Rev.1

Figure 6. Water Activity as a Function of $\mathrm{KNO}_{3}$ Ionic Strength at 298.15 K.

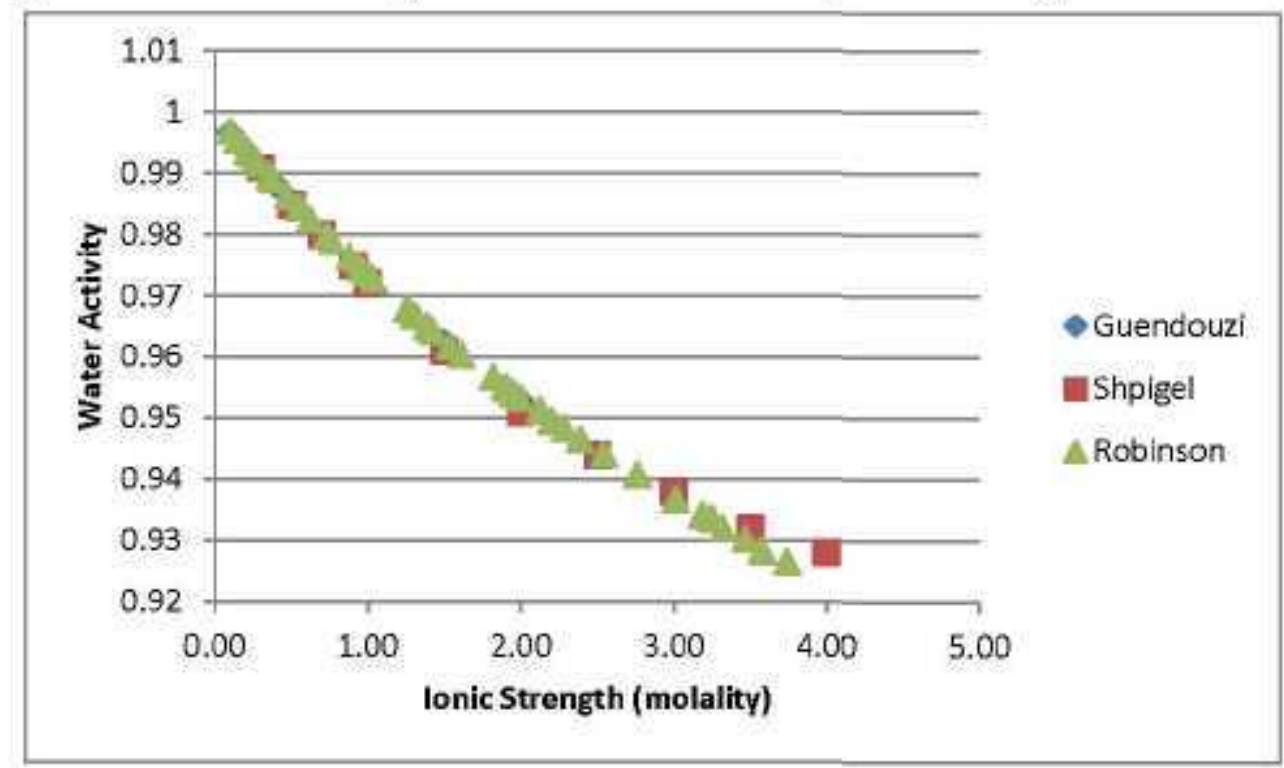




\section{FUTURE WORK}

In this report literature data is presented, analyzed, and examined for its suitability for use in calculating water activity under Hanford relevant temperature and solute concentration conditions. The goal of this effort will be to use water activity in calculating solubility of Hanford tank waste solid phases. Suitability was based on agreement between water activity as a function of ionic strength, for single solutes, as examined among multiple data sources. A total of six single solutes were examined.

In future follow-on work, these datasets will be used to develop models of water activity versus ionic strength and temperature. These models will enable solutions made from mixtures of solutes to calculate water activity based on single solute water activity data versus concentration and temperature. The ultimate objective of this ongoing task will be to extend these single solute water activities to multiple, mixed, solute systems to calculate solids formation in Hanford operations based on a predictive model. In future work this formalism and application will be extended to additional solutes, as well as incorporating ternary and higher mixed solute solutions to develop model parameterizations for Hanford-relevant wastes. Additional solutes to be examined in the future include: $\mathrm{NaOH}, \mathrm{NaF}, \mathrm{Na}_{2} \mathrm{C}_{2} \mathrm{O}_{4}, \mathrm{Na}_{3} \mathrm{PO}_{4}, \mathrm{KOH}, \mathrm{KNO}, \mathrm{KCl}, \mathrm{K}_{2} \mathrm{CO}_{3}$, $\mathrm{KF}$, and $\mathrm{K}_{2} \mathrm{SO}_{4}$, as well as ternary solids such as $\mathrm{NaAl}(\mathrm{OH})_{4}$. 


\section{REFERENCES}

\subsection{GENERAL REFERENCES}

RPP-PLAN-46002 Rev.0, Reynolds, J.G., Wash and Leach Factor Work Plan, Washington River Protection Solutions, 13 August 2010.

Aseyev, G.G., and S.N. Gorin, 1999, "Electrolytes: Equilibria in Solutions and Phase Equilibria. Calculation of Multicomponent Systems and Experimental Data on the Activities of Water, Vapor Pressures, and Osmotic Coefficients", Begelll House Inc. Publishers, New York.

Goff, J.A., Gratch, S., 1946, "Low-Pressure Properties of Water from - 160 to 212 F", Transactions of the American Society of Heat and Ventilation Engineering, 52, pp. 95 121.

Murray, F.W., 1967, "On the Computation of Saturation Vapor Pressure", Journal of Applied Meteorology, 6, pp. 203-204.

Tank Waste Information Network System (TWINS), Queried 9/22/2010, http://wins.pnl.gov/data/datamenu.htm

Zemaitis Jr., J.F., and D.M. Clark, M. Rafal, N.C. Scrivner, 1986, Handbook of Aqneons. Electrolyte Thermodynamics: Theory \& Application, Design Institute for Physical Property Data (AIChE), New York.

\subsection{WATER ACTIVITY REFERENCES}

\subsection{1 $\mathrm{NaNO}_{3}$}

Galleguillos, H. and D. Salavera, P. Vargas, A. Coronas, 2010, "Experimental Determination and Prediction of the Vapor Pressure of some Binary and Quaternary Aqueous Solutions of Alkaline Nitrites and Nitrates", Fluid Phase Equilibria, 291, pp. 208-211.

Apelblat, A., and E. Korin, 1998, "The Vapor Pressures of Saturated Aqueous Solutions of Sodium Chloride, Sodium Bromide, Sodium Nitrate, Sodium Nitrite, Potassium Iodate, and Rubidium Chloride at Temperatures from $227 \mathrm{~K}$ to $323 \mathrm{~K}$, Journal of Chemical Thermodynamics, 30, pp. 59-71.

Voigt, W., A. Dittrich, B. Haugsdal, K. Grjotheim, 1990, "Thermodynamics of Aqueous Reciprocal Salt Systems. II. Isopiestic Determination of the Osmotic and Activity Coefficients in $\mathrm{LiNO}_{3}-\mathrm{NaBr}-\mathrm{H}_{2} \mathrm{O}$ and $\mathrm{LiBr}-\mathrm{NaNO}{ }_{3}-\mathrm{H}_{2} \mathrm{O}$ at 100.3 Celcius", Acta Chemica Scandinavica, 44, pp. 12-17.

Bossmann, E., J. Richter, A. Stark, 1993, "Experimental Results and Aspects of Analytical Treatment of Vapour Pressure Measurements in Hydrated Melts at Elevated Temperatures", Ber. Bunsenges Physical Chemistry, 97, pp. 240-245.

Pearce, J.N., and H. Hopson, 1937, "The Vapor Pressures of Aqueous Solutions of Sodium Nitrate and Potassium Thiocynate", Journal of Physical Chemistry, pp. 535-538.

Kangro, W., and A. Groeneveld, 1962, "Kozentrierte wassrige Losungen, I", Zeitschrift fur Physikalische Chemie Neue Folge, 32, pp. 110-126. 
Shpigel, L.P., and K.P. Mishchenko, 1967, "Activities and Rational Activity Coefficients of Water in Potassium Nitrate and Sodium Nitrate Solutions at 1, 25, 50, and 75 Celcius Over a Wide Concentration Range", Joumal of Applied Chemistry USSR, 40, pp. 659661.

\subsection{2 $\mathrm{NaNO}_{2}$}

Galleguillos, H. and D. Salavera, P. Vargas, A. Coronas, 2010, "Experimental Determination and Prediction of the Vapor Pressure of some Binary and Quaternary Aqueous Solutions of Alkaline Nitrites and Nitrates", Fluid Phase Equilbria, 291, pp. 208-211.

Ray, J.D., and R.A. Ogg, Jr., 1956, "The Anomolous Entropy of Potassium Nitrite", 60, pp. 1599-1600.

Chekhunova, N.P., and P.I. Protsenko, 1967, "Activity Coefficients of the Nitrites of Sodium, Potassium, and Magnesium", Russian Journal of Physical Chemistry, 41, pp. 1220-1221.

\subsubsection{NaCl}

Apelblat, A., and E. Korin, 1998, "The Vapor Pressures of Saturated Aqueous Solutions of Sodium Chloride, Sodium Bromide, Sodium Nitrate, Sodium Nitrite, Potassium Iodate, and Rubidium Chloride at Temperatures from $227 \mathrm{~K}$ to $323 \mathrm{~K}$ ", Journal of Chemical Thermodynamics, 30 , pp. 59-71.

Gibbard Jr., H.F. and G. Scatchard, R.A. Rousseau, J.L. Creek, 1974, "Liquid-Vapor Equilibrium of Aqueous Sodium Chloride, from 298 to $373 \mathrm{~K}$ and from 1 to 6 mol $\mathrm{kg}^{-1}$, and Related Properties", Journal of Chemical Engineering Data, 19, pp. 281-288.

Hubert, N. and Y. Gabes, J.-B. Bourdet, L. Schuffenecker, 1995, "Vapor Pressure Measurements with a Nonisothermal Static Method between 293.15 and $363.15 \mathrm{~K}$ for Electrolyte Solutions. Application to the $\mathrm{H}_{2} \mathrm{O}+\mathrm{NaCl}$ System", Journal of Chemical Engineering Data, 40, pp. 891-894.

Olynyk, P., and A.R. Gordon, 1943, "The Vapor Pressure of Aqueous Solutions of Sodium Chloride at 20,25, and 30 Celcius for Concentrations from 2 Molal to Saturation", Journal of the American Chemical Society, 65, pp. 224-226.

\subsection{4 $\mathrm{Na}_{2} \mathrm{CO}_{3}$}

Vanderzee, C.E., 1982, "Thermodynamic Properties of Solutions of a Hydrolyzing Electrolyte: Relative Partial Molar Enthalpies and Heat Capacities, Solvent Activities, Osmotic Coefficients, and Solute Activity Coefficients of Aqueous Sodium Carbonate", Joumal of Chemical Thermodynamics, 14, pp. 1051-1067.

Appleblat, A. and E. Manzurola, 2003, "Solubility's and Vapour Pressures of Saturated Aqueous Solutions of Sodium Tetraborate, Sodium Carbonate, and Magnesium Sulfate and Freezing-Temperature Lowerings of Sodium Tetraborate and Sodium Carbonate Solutions, Journal of Chemical Thermodynamics, 35, pp. 221-238.

Robinson, R.A, and J.B. Macaskill, 1979, "Osmotic Coefficients of Aqueous Sodium Carbonate Solutions at $25^{\circ} \mathrm{C}$ ", Journal of Solution Chemistry, 8, pp. 35-40.

Taylor, C.E., 1955, "Thermodynamics of Sodium Carbonate in Solution", Journal of Physical Chemistry, 59, pp. 653-657. 


\subsection{5 $\mathrm{Na}_{2} \mathrm{SO}_{4}$}

Guendouzi, M.E., and A. Mounir, A. Dinane, 2003, "Water Activity, Osmotic and Activity Coefficients of Aqueous Solutions of $\mathrm{Li}_{2} \mathrm{SO}_{4}, \mathrm{Na}_{2} \mathrm{SO}_{4}, \mathrm{~K}_{2} \mathrm{SO}_{4},\left(\mathrm{NH}_{4}\right)_{2} \mathrm{SO}_{4}, \mathrm{MgSO}_{4}$, $\mathrm{MnSO}_{4}, \mathrm{NiSO}_{4}, \mathrm{CuSO}_{4}$, and $\mathrm{ZnSO}_{4}$, at $\mathrm{T}=298.15 \mathrm{~K}$, Journal of Chemical Thermodynamies, 35, pp. 209-220.

Rard, J.A. and S.L. Clegg, D.A. Palmer, 2000, "Isopiestic Determination of the Osmotic Coefficients of $\mathrm{Na}_{2} \mathrm{SO}_{4}(\mathrm{aq})$ at 25 and $50^{\circ} \mathrm{C}$, and Representation with Ion-Interaction (Pitzer) and Mole Fraction Thermodynamic Models, Journal of Solution Chemistry, 29, pp. 1-49.

Leopold, H.G. and J. Johnston, 1927, "The Vapor Pressure of the Saturated Aqueous Solutions of Certain Salts", Joumal of the American Chemical Society, 49, pp. 1974-1988.

Robinson, R.A. and J.M. Wilson, R.H. Stokes, 1941, "The Activity Coefficients of Lithium. Sodium, and Potassium Sulfate and Sodium Thiosulfate at $25^{\circ} \mathrm{C}$ from Isopiestic Vapor Pressure Measurements", Journal of the American Chemical Society, 63, pp. 1011-1013.

Rard, J.A., and D.G. Miller, 1981, "Isopiestic Determination of the Osmotic Coefficients of Aqueous $\mathrm{Na}_{2} \mathrm{SO}_{4}, \mathrm{MgSO}_{4}$, and $\mathrm{Na}_{2} \mathrm{SO}_{4}-\mathrm{MgSO}_{4}$ at 25 Celcius", Journal of Chemical Engineering Data, 26, pp. 33-38.

Gibson, R.E., and L.H. Adams, 1933, "Changes of Chemical Potential in Concentrated Solutions of Certain Salts". Journal of the American Chemical Society, pp. 2679-2695.

Humphries, W.T., C.F. Kohrt, C.S. Patterson, 1968, "Osmotic Properties of Some Aqueous Electrolytes at 60 Celcius", 13, pp. 327-330.

Moore, J.T., W.T. Humphries, C.S. Patterson, 1972, "Isopiestic Studies of Some Aqueous Electrolyte Solutions at 80 Celcius", 17, pp, 180-182.

Hellams, K.L., C.S. Patterson, B.H. Prentice III, M.J. Taylor, 1965, "Osmotic Properties of Some Aqueous Solutions at 45 Celcius", 10, pp. 323-325.

Patterson, C.S., L.O. Gilpatrick, B.A. Soldano, 1960, "The Osmotic Behavior of Representative Aqueous Salt Solutions at 100 Celcius", Journal of the Chemical Society, pp. 2730-2734.

Soldano, B.A., and C.S. Patterson, 1962, "Osmotic Behavior of Aqueous Salt Solutions at Elevated Temperatures, Part II", Journal of the Chemical Society, pp. 937-940.

\subsection{6 $\mathrm{KNO}_{3}$}

Guendouzi, M.E, and A. Mounir, A. Dinane, 2003, "Water Activity, Osmotic and Activity Coefficients of Aqueous Solutions of $\mathrm{Li}_{2} \mathrm{SO}_{4}, \mathrm{Na}_{2} \mathrm{SO}_{4}, \mathrm{~K}_{2} \mathrm{SO}_{4},\left(\mathrm{NH}_{4}\right)_{2} \mathrm{SO}_{4}, \mathrm{MgSO}_{4}$, $\mathrm{MnSO}_{4}, \mathrm{NiSO}_{4}, \mathrm{CuSO}_{4}$, and $\mathrm{ZnSO}_{4}$, at T=298.15 K", Journal of Chemical Thermodynamics, 35, pp. 209-220.

Shpigel, L.P., and K.P. Mishchenko, 1967, "Activities and Rational Activity Coefficients of Water in Potassium Nitrate and Sodium Nitrate Solutions at 1, 25, 50, and 75 Celcius Over a Wide Concentration Range", Journal of Applied Chemistry USSR, 40, pp. 659661 . 
Robinson, R.A., 1935, "The Activity Coefficients of Alkali Nitrates, Acetates, and pToluenesulfonates in Aqueous Solution from Vapor Pressure Measurements", Journal of the American Chemical Society, 1165-1168.

Kangro, W., and A. Groeneveld, 1962, "Kozentrierte wassrige Losungen, I", Zeitschrift fur Physikalische Chemie Neue Folge, 32, pp. 110-126. 


\section{DISTRIBUTION SHEET}

To

J.G. Reymolds

Documentiprojecl TitleW Work Onder

Water Activity Data Assessment to be used in Hanford Waste Solubility Calculations
Pags 1 of 1

Date 1/6/2011

EOT No. NA

ECN No. NA

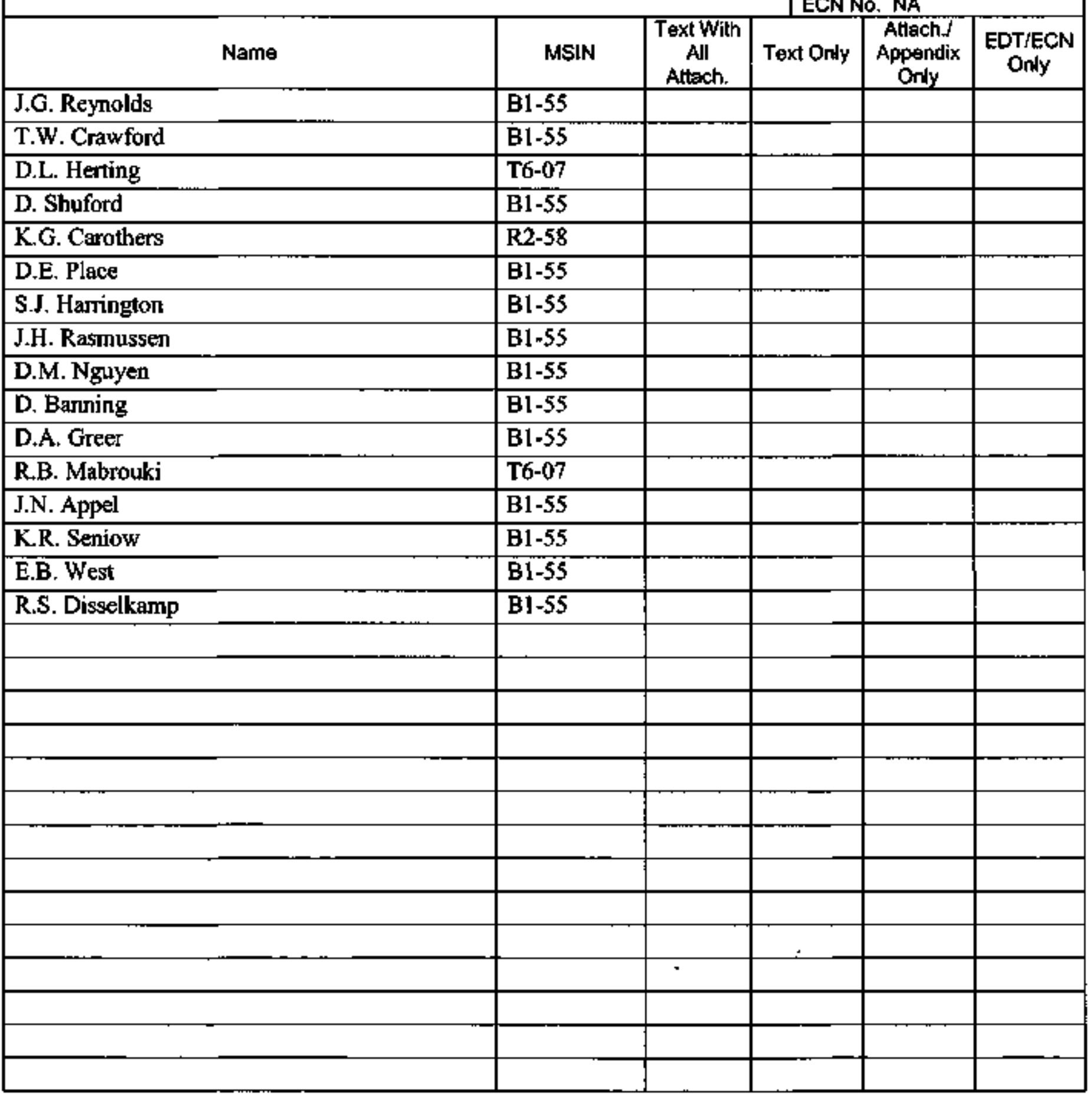

